\title{
Why Chinese Companies Go Abroad? A Theoretical Model to Explain the Drivers of the Internationalization Strategy of Chinese MNEs
}

\author{
Adele Parmentola ${ }^{1}$ \\ ${ }^{1}$ Department of Management and Quantitative Studies, Università degli studi di Napoli Parthenope, Via Generale \\ Parisi, 13, 80132, Napoli, Italy \\ Correspondence: Adele Parmentola is Associate Professor at Department of Management and Quantitative \\ Studies, Università degli Studi di Napoli Parthenope, Via Generale Parisi, 13, 80132, Napoli, Italy. \\ Received: July 26, 2017 \\ doi:10.5539/ibr.v10n10p82 \\ Accepted: August 30, $2017 \quad$ Online Published: September 7, 2017 \\ URL: https://doi.org/10.5539/ibr.v10n10p82
}

\begin{abstract}
China is today considered the second power in the world after the USA and recently many Chinese companies became global leaders in their specific industries. This success is also realized thanks to the expansion strategy adopted by many Chinese multinationals that have realized FDIs both towards other developing countries and towards advanced economies. What are the determinants that push the Chinese companies to go abroad? Are the traditional internalization theories based on the concept of ownership advantage able to explain the internationalization of Chinese MNES? Accordingly aim of this paper is to describe the determinants that induce the Chinese companies to realize FDIs and the characteristics that distinguish their internationalization strategy by the strategy adopted by developed countries multinationals.
\end{abstract}

Keywords: internationalization strategy; FDIs; Chinese companies; telecommunication equipment industry

\section{Introduction}

Today China is considered by many scholars the second world power after the United States. This extraordinary economic growth was driven by the choices made by Chinese companies that nowadays appear to be world leaders so much that many are cited in the prestigious Fortune 500 rankings. In particular, recent international rankings show how Chinese companies are the first places for a number of Foreign Direct Inve stments (FDI) (UNCTAD, 2015).

By analyzing the characteristics of the international development strategy of Chinese companies, a number of peculiarities emerge that are in some ways unexplainable, considering the traditional theories of internationalization. Since the beginning of its international development, Chinese companies have invested in developed countries, even though this meant dealing with much more advanced local companies.

In addition, Chinese multinationals have since the beginning internationalized the most value-added activities. All this makes the internationalization of Chinese companies difficult to interpret from the traditional theory of internationalization based on the concept of ownership advantage (Child \& Rodriguez, 2005).

On the basis of these considerations, the international expansion of Chinese MNEs seems an interesting and unexplored area of study. Exploring the international strategy that Chinese companies have adopted in the past it is also useful to understand the reasons of the actual success of these companies.

Only in the last few years some studies appeared regarding the phenomenon of recent growth of Chinese multinationals. Nevertheless, many of these studies describe, adopting the mainstream literature on multinationals' development, only specific aspects of the Chinese multinational development (Deng, 2004; Hong $\&$ Sun, 2004; Wu, 2005).

Consequently, the aim of this paper is to analyse the international expansion of Chinese companies answering to the following research questions:

-What are the determinants that push the Chinese companies to go abroad?

-Are the traditional internalization theories based on the concept of ownership advantage able to explain the internationalization of Chinese MNES?

The paper is articulated as follows: in the following section a theoretical background is described, then a 
theoretical model is presented to explain the determinants of the internationalization of Chinese Companies, finally the model is explained analysing the story of the internationalization of four Chinese companies.

\section{Theoretical Background}

Since the 1970s, scholars have been analysed the determinants that drive companies to realize FDIs. Economists have traditionally stressed how companies are driven for internationalization from the need to exploit their own benefits in other countries in order to improve their profits (Caves, 1971; Hymer, 1976). Other studies have focused on exploiting the imperfections of foreign markets to acquire low-cost productive resources (McManus, 1972; Buckely \& Casson, 1976; Rugman, 1981; Hennart, 1982).

From a different perspective, Vernon (1966), describing the international development of American multinationals, stated that international development was dictated by the need to find outlet markets for their products that had reached the maturity stage in the home market. Knickerbocker (1973) affirmed that a firm carries out FDIs in a specific foreign market in order to imitate the strategy of large competitors.

Other authors based on the Transaction Costs Approach (Coase, 1937; Williamson, 1975) describe the creation of FDI as a process useful to internalize transactions by reducing the costs associated with resources acquisition on the foreign market (Buckley \& Casson, 1976; Hennart, 1982).

From a different perspective, the evolutionary approaches to internationalization underlined that a firm can realize FDIs only during the last stage of its internationalization experience. In fact, according to these approaches, internationalization is a process made up by different stages (Andersen, 1992), with the move from one stage to another being determined by increases either in resources control (Cavusgil,1980; Rugman,1982) or market knowledge (Johanson \& Vahlne, 1977; Reid, 1981; Chang \& Singh-Chang, 1992).

Synthesizing the most important approaches, Dunning (1988) affirmed that the existence of MNEs reflects the interplay of three sets of advantages: ownership, location and internalization (OLI):

- Ownership advantages are those that enable particular firms to grow and diversify more successfully than others at home or abroad. These advantages are based on the firm's specific characteristics and on its ability to accumulate specific intangible assets;

- Location advantages arise at the country rather at the firm level and determine the sites where ownership advantages will be exploited;

- Internalization advantages are related to the ways a firm chooses to exploit its ownership advantages (market or hierarchy).

All of these approaches (classical and more recent) are based on the hypothesis that the internationalisation choice is driven by the desire to exploit existing resources (its ownership advantages) in wider markets and to increase them with new available resources (Penrose,1956). Therefore, only those firms that have sufficient resources are able to internationalize in foreign markets. Moreover, according to these studies a company can realize FDIs only in countries characterised by levels of development equal to or lower than those present at home because only in these countries it is able to exploit its ownership advantages ${ }^{1}$.

On the other hand, some classical approaches (Vernon, 1966; Chandler, 1977) suggest that the development strategy of firms follows a well-established path and it is motivated by the firms' necessity to expand their size. As a result, a firm begins to go abroad only after having reached the maximum expansion level in the home country. These theories, however, do not appear equipped to explain internationalization by firms coming from emerging and less developed countries as these firms are able to go abroad, also towards developed countries, without the ownership of specific advantages and without occupying a strong competitive position in the home country.

In past years, some authors have tried to describe the rise of Third World Multinationals (TWMNE) but have interpreted this phenomenon by using the traditional approaches based on the idea that Third World Multinationals are able to go abroad because they have particular ownership advantages to exploit via internationalization in other emerging countries. For example Wells (1981) affirmed that TWMNEs have particular ownership advantages comparing to developed countries' MNEs when they decide to internationalize in other emerging countries. The sources of these advantages include: (1) less use of specialized machines that favour the adaption of the productive process to foreign market inputs; (2) mature and more universal products,

\footnotetext{
${ }^{1}$ Ownership advantages are not due only to the characteristics of the company (Schroath et al., 1992; Dunning,
} 1998), but also to the characteristics of the country where they must been exploited (Eramilli et al., 1997). 
which better match the lower standards of machinery and equipment in local downstream firms; (3) small scale of operations; and (4) the flexibility stemming from lower specialisation that easy the process of adaptability to change of external conditions.

Other authors underlined that TWMNEs go abroad to exploit the ownership advantages based on the low labour costs of the home country (Ghymn, 1980; Khan 1986).

Lall (1984) affirmed that the ownership advantages of developing countries' MNES are expected to vary by activity and by home country and increase when the level of firm's knowledge and experience grows.

According to Tolentino (1992), the ownership advantage of firms from developing countries is based on their ability to: (1) imitate and adapt foreign technology in accordance with developing countries' markets and production conditions; (2) innovate on essentially different lines from those of the more advanced countries; and (3) achieve improvements by modernising older technique, including foreign outdated technology. Other possible sources of ownership advantage of developing-country MNEs are the presence of ethnic connections, the specialization in products not made by developed countries' MNEs, the cultural similarity with the host country, the high level of acceptance by many host governments (Kumar, 1982). Nevertheless, these kinds of ownership advantages are valid when Third World firms invest in other developing countries, but they could not be considered sources of competitive advantages when they invest in developed countries.

Accordingly, given the importance of ownership advantages in FDIs, it follows that FDIs from developing countries is likely to be directed toward countries with economic, cultural and ethnical proximity and only when the company has acquired more market and technical knowledge can invest in countries with larger geographical, cultural or ethnical distance (Ferrantino, 1992).

Summarizing, both the analysed approaches consider that:

- a company can realize FDIs only in countries characterised by same or lower development levels than those existing in the domestic country;

- a company can invest abroad only after having reached a strong competitive position in the domestic market and after having accumulated some exceeding resources.

In contradiction to the first affirmation, some empirical studies show that many firms realise FDIs also in countries characterised by a higher level of development than in the domestic market, because they are driven by the need to acquire new knowledge. This is, for example, the international strategy adopted by some European and Japanese ITC companies that delocalised their R\&D activities to the US Silicon Valley (Dunning, 1993; Chang, 1995; Almeida, 1996).

Accordingly, Moon and Rohel (2001), analysing unconventional FDIs ${ }^{2}$, underline that what induces the companies investing abroad is their disadvantageous position in the domestic market. Some firms, therefore, decide to realize FDIs because they are not able to obtain a competitive advantage in the domestic market ${ }^{3}$.

In this sense, the internationalization strategy of the firm is not motivated by an expansion aim by it is imposed by the necessity.

According to this, in order to describe the international strategy of Chinese MNEs, it seems necessary to identify a new theoretical framework deals with the case that emerging countries' MNEs realise FDIs in developed countries as well as the fact that a company goes abroad to overcome its competitive disadvantages rather than for exploiting its ownership advantages.

\section{Theoretical Framework}

As explained above, in order to understand the internationalization strategy of emerging countries' MNEs, it is necessary to overcome the hypothesis that a company can realize FDIs only after having reached a strong competitive position in the domestic market. Moreover, the consideration that emerging countries' MNEs can realize FDIs only in other emerging countries because only in these countries are they able to exploit their ownership advantages it is not generally applicable.

${ }^{2}$ Unconventional FDI is that realized by non-dominant firms or by LDC MNEs in developed countries (Moon \& Roehl, 2001).

${ }^{3}$ This latter theory is coherent with the position of Dawar \& Frost (1999), which views internationalization as a way for local firms to defend themselves against the high competitive pressure imposed in the home countries by the foreign multinationals. 
According to these latter considerations, in order to analyse the motivations that induce Chinese MNEs to realize FDIs, two dimensions have been adopted:

- the level of a firm's competitiveness in the domestic market;

- the level of socio-economic development of the destination country.

\section{The level of firm's competitiveness in the domestic market}

This dimension measures the firm's competitiveness in the domestic market in comparison to competitors. In other words, the level of competitiveness is high when the firm has already gained a strong competitive advantage and, consequently, it is leader in the domestic market; on the other hand, the level of competitiveness is low when the firm is not able to build a sustainable competitive advantage in comparison to that achieved by competitors.

This dimension is somewhat complex and can be evaluated by considering the interplay of three different aspects: the resources and competences owned by the firm, the characteristics of the industry, the firm's market share.

\section{The level of socio-economic development of the destination country}

This dimension synthesises the characteristics of the localization area and consequently identifies what kind of resources and competences the firm can obtain by realizing FDIs in a specific place. In particular, the level of socio-economic development is high in developed countries and, generally, in contexts characterised by the presence of qualified employees, innovative tradition, and knowledge intensive areas. On the other hand, the level of socio-economic development is low in under developed and developing countries and generally in contexts characterised only by low cost productive factors.

It is necessary to underline that the distinction between contexts with high and low socio-economic development levels only partially coincides with the OCSE classification of developed and de veloping countries. For example, traditionally India is considered a de veloping country, but there are some Indian regions -i.e. Bangalore- that are characterised by a high level of socio economic development.

Consequently, in order to evaluate the socio-economic development level of the destination country, the interplay of three sets of indicators has been taken into account: macroeconomic indicators - GNP, Foreign Debt, import/export rate -; technology de velopment indicators - R\&D expenses, number of graduates, number of high-tech companies-; infrastructural indicators - number of ports, airports, railways, roads per inhabitant, financial market capitalization rate -.

Adopting the explained dimensions, four kinds of determinants that can induce a company to realize FDIs in a specific country are shown in figure 1 .

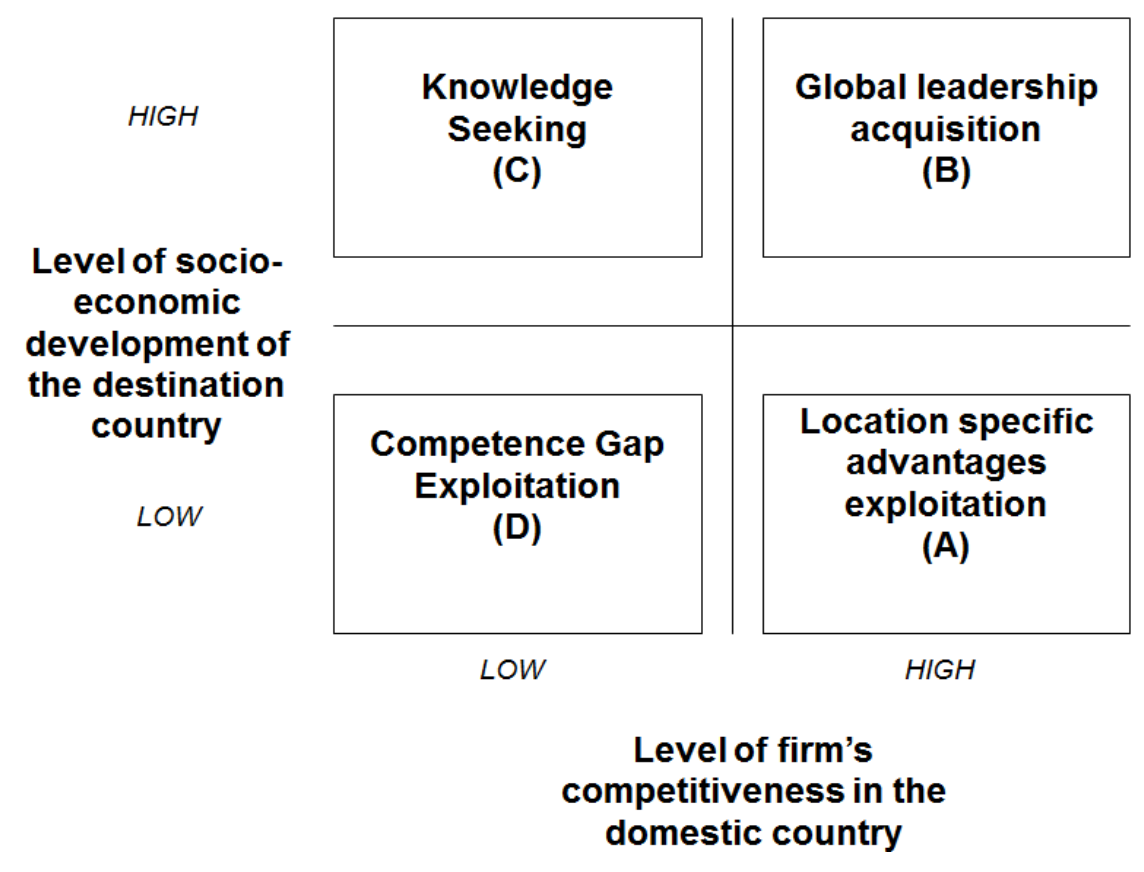

Figure 1. Theoretical framework 
Quadrant A (Location Specific Advantages Exploitation): this quadrant could be used to classify the cases of the internationalization of large multinationals which, having built a sustainable competitive advantage in the domestic market, realize FDIs in developing countries so as to exploit the host countries' resources as a means of increasing their market share and acquiring low cost resources. This kind of determinant has been well explained by classical internationalization theories based on the analysis of expansion strategies adopted by large American Corporations.

Quadrant B (Global Leadership Acquisition): this quadrant explains the case of companies which, having built a sustainable competitive advantage in the domestic market, leave their countries because they want to reinforce their global competitive position and to build a global advantage. Unlike the previous case, their growth strategy is aimed not to acquire low cost resources and to enlarge destination markets, but to acquire new technological and managerial knowledge. Consequently, they are attracted by countries with high socioeconomic development. These firms know that, despite having a strong competitive advantage in their domestic market, they need to acquire and to continually increase their knowledge to become global competitors. This is particularly true for firms that operate in innovative and high competitive industries and is illustrated by the internationalization strategies adopted by Japanese and European firms in the US (Kogut \& Chang, 1991; Almeida, 1996.).

Quadrant C (Knowledge Seeking): this quadrant explains the case of companies which, forced to go abroad by the high costs and competitive pressure of the home country, wish to improve their competitive position in the domestic market. Consequently, they decide to invest in countries characterised by high levels of socioeconomic development where they can acquire the strategic assets necessary to reinforce their competitive position in the home country. In this case, internationalization is a temporary solution, because the firms that adopt this strategy usually leave the foreign market after having acquired the necessary strategic assets in order to concentrate its resources in the home market.

Quadrant D (Competence Gap Exploitation): explains the case of firms, often coming from emerging countries, which are forced to go abroad as a result of conditions in the home country. These companies, unlike those illustrated in quadrant $\mathrm{C}$, decide to invest in countries characterised by a level of low socio- economic development because in these countries they are able to exploit their existing assets. In this case, internationalization is a defensive strategy, adopted by companies that cannot survive in the home country and which, instead of acquiring the necessary assets to compete in the home market, prefer to change the destination of their resources. In other words, these companies realize FDIs in countries characterised by low socio economic-development level because in these contexts they can exploit the positive competence gap over local competitors.

The proposed model has been interpreted in a dynamic way; in fact, a firm can change its strategy during the different phases of its life (a possible evolution is indicated in figure 1 with the arrows). For example, a company can start its international development process driven by a Knowledge Seeking motivation, then, having acquired the knowledge necessary to reinforce its position in the home market, can change its motivations and can decide to realize FDIs in a less developed country in order to exploit the location advantages.

\section{Methodology}

In order to verify the validity of the proposed theoretical model to explain the determinants of international expansion of Chinese companies the study relies on a multiple-case study analysis (Yin, 1994; Eisenhardt, 1989; Gillham, 2000) and adopts a "synthetic strategy" for the analysis of process data.

Six cases of Chinese firms operating in the same industry - the telecommunications equipment industry - are analysed in order to eliminate all distortions determined by cross-industry differences.

Research Setting. The different cases were selected by adopting a well established criterion. First, the list of the China Top 100 Leading Domestic Electronics and IT Companies supplied by the Chinese Ministry of Information Industry is examined. Then, all the companies that are part of the Communications Equipment Industry (USSIC 366 and NACE 3230) and are wholly Chinese (I did not consider WFOEs and Sino-foreign Joint Ventures) are selected. Analysing the remaining companies, only those firms that have at least one subsidiary in a foreign country or have created an international equity alliance with a foreign firm are selected.

Data Collection. The data were collected, according to the multiple cases study approach (Yin, 1994), using different sources (company reports; articles; local newspapers; research database; company websites).

Data Analysis. According to the multiple cases approach, the single cases were closely analysed. In particular, the international activities of each firm are analysed by adopting a chronological criterion (starting from the 
firm's foundation until the last year). Then for every firm the level of competitiveness in the domestic market and the level of socio-economic development of the destination country is examined.

Finally, adopting a comparative logic close to the one described by Eisenhardt (1989) comparative tables are built to identify discriminating variables in order to identify the determinants of international expansion of the analysed companies.

\section{Empirical Evidence: The International Strategy of Chinese Communications Equi pment Manufacturers}

The communications equipment industry is characterized by firms that offer technological and physical solutions (LAN and WAN systems, routers, telephones, switchboards and exchanges) to telecommunication companies operating both in the fixed, mobile and internet communication segments.

China's telecom-equipment market is one of the fastest growing and most competitive in the world. In fact, China's telecommunication infrastructure has experienced extraordinary progress over the last two decades as the government has given great priority to strengthen it to meet the accelerated growth in demand for telecom services.

During 2007 the Chinese communications equipment market generated total revenues of $\$ 27.9$ billion, representing a compound annual growth rate (CAGR) of 4.5\% for the period spanning 2003-2007.

The sales of telephony and terminals proved the most lucrative for the Chinese communications equipment market in 2007, generating total revenues of $\$ 24$ billion, equivalent to $86.3 \%$ of the market's overall value.

Analysing the competitive landscape, the threat of new entrants into the communications equipment market is moderate. A high level of product differentiation combined with high fixed costs of manufacturing facilities present significant entry barriers for new players.

On the other hand, the increasing need for wired, and even greater, for wireless communication equipment and at the same time the lack of a substitute for this kind of equipment makes the threat of substitutes to the communications equipment market almost not existent.

The typical supplier of the components needed by players is usually large international companies. Electrical components are the key raw materials for the manufacture of communications equipment and the quality of these raw materials is a key issue and often players are inclined to buy more expensive products but of better quality or with a better/longer guarantee for the component This reduces supplier power. Additionally, owing to the lack of product diversification, switching costs are small and usually involve only the time needed for the switching process. Vertical integration between electrical component manufacturers and the player is uncommon, with the exception of large technology companies such as Motorola. Overall, suppliers' power with respect to the networking of equipment manufacturing is moderate.

The increasing commoditisation of communications equipment, however, indicates an increase in buyers' power, although the level of diversification of equipment is very high. Furthermore, the fast-growing markets of China, Indonesia or Vietnam increase the number of end - users and decrease even more buyers' power. The potential of vertical backwards and forward integration in that market is not very likely especially as the buyers are end-users of the equipment. Overall, buyers' power within the communications equipment market is moderate.

Analysing the direct competitors, larger players within the industry are multinational players such as Cisco, Lucent Technologies Inc, Nokia or Motorola, amongst which there is fierce competition despite a high degree of product differentiation. In fact, echoing market growth, most of the global sector leaders started their operations in China in the 1980s and 1990s: Cisco, Ericsson, Lucent Technologies, Motorola, Nokia, Nortel Networks, and Siemens.

The presence of MNCs has facilitated the building of China's telec ommunications infrastructure; howe ver, it has posed great challenges for domestic firms as well. In the 1980s, China relied on $100 \%$ of its acquisition of telecommunication equipment through imports.

Despite the challenges, domestic firms have advanced rapidly. The initial growth of Chinese equipment vendors was nurtured by a vast domestic market and the Chinese government's support for technology development, but Chinese vendors have increasingly been seeking expansion overseas, in part because China's telecom capital spending turned stagnant and pricing pressure mounted. Propelled by their lower manufacturing costs and by increasing investments in innovation, Chinese telecom equipment vendors have achieved leading positions in some product segments worldwide. On the other hand, the increasing competitive pressure of foreign multinationals and the convergence of fixed-line and wireless businesses in the telecom industry (large scale production necessity) led to a wave of mergers between local producers. 
To sum up, the Chinese communication equipment market is characterized by the high competitive pressure exercised by international multinationals, by the increasing concentration of the local operators and by continuing technological innovations. However, the Chinese market presents a high growth potential as a result of increasing demand of telecommunication services. These particular conditions could induce local firms to adopt the international strategy as a defensive solution. This strategy is aimed either at acquiring the knowledge necessary for obtaining a competitive advantage in internal markets or at concentrating resources in foreign markets characterized by a lower competitive pressure.

In order to examine in a specific way the determinants of international expansion of Chinese Telecommunication Equipment manufactures the cases of six Chinese Telecommunication Equipment manufacturers are analysed: Huawei Technologies Co. Ltd, Zhongxing Telecommunication Equipment (ZTE) Co. Ltd, Datang Telecom Technology Co. Ltd, Panda Electronics Group Co. Ltd, Putian Communication Group Co. Ltd, TCL Communication Equipment Co. Ltd (the characteristics of analysed companies are summarised in table1)

Table 1. Main characteristics of selected companies

\begin{tabular}{lllllll}
\hline & $\begin{array}{l}\text { Huawei } \\
\text { Technolo } \\
\text { gies } \\
\text { Co.Ldt }\end{array}$ & $\begin{array}{l}\text { Zhongxing } \\
\text { Telecommuni } \\
\text { cation } \\
\text { Equipment } \\
\text { (ZTE) Co. } \\
\text { Ldt }\end{array}$ & $\begin{array}{l}\text { Datang } \\
\text { Telecom } \\
\text { Technolo } \\
\text { gy Co. } \\
\text { Ldt }\end{array}$ & $\begin{array}{l}\text { Panda } \\
\text { Electron } \\
\text { ics } \\
\text { Group } \\
\text { Co. Ldt }\end{array}$ & $\begin{array}{l}\text { Putian } \\
\text { Communicat } \\
\text { ion Group } \\
\text { Co. Ldt }\end{array}$ & $\begin{array}{l}\text { TCL } \\
\text { Communicat } \\
\text { ion } \\
\text { Equipment } \\
\text { Co. Ldt }\end{array}$ \\
\hline $\begin{array}{l}\text { Corporate } \\
\text { Localization }\end{array}$ & Shenzhen & Shenzhen & Hangzhou & Nanjing & Bejing & Heizhou \\
\hline $\begin{array}{l}\text { Ownership } \\
\text { of }\end{array}$ & Private & Pubblic Company & $\begin{array}{l}\text { Partially state } \\
\text { owned }\end{array}$ & $\begin{array}{l}\text { Pubblic } \\
\text { Company }\end{array}$ & Private & Partially \\
owned
\end{tabular}

Firstly, the companies' competitive position in the domestic market is examined. Prior to 2004, foreign multinationals held the leadership in the Chinese market, in particular, Cisco System and Alcatel Lucent were leaders in fixed network segment and Motorola, Nokia and Ericsson were leaders in the mobile segment.

Thus, all the analysed companies showed a low level of competitiveness in the domestic market. The conditions changed after 2004, when two of the analysed companies, Huawei and ZTE, increased their market shares to become leaders, respectively, in the fixed and mobile segment.

Then international activities of the single firms by adopting a chronological criterion (starting from the firm's foundation) are analysed. The phases of international expansion of the companies are summarised in table 2 . 
Table 2. The phases of international expansion of Chinese Telecommunication Equipment Manufacturers

\begin{tabular}{|c|c|c|c|c|c|}
\hline $\begin{array}{l}\text { Huawei } \\
\text { Technologies } \\
\text { Co.Ldt }\end{array}$ & $\begin{array}{l}\text { Zhongxing } \\
\text { Telecommunicatio } \\
\text { n Equipment } \\
\text { (ZTE) Co. Ldt }\end{array}$ & $\begin{array}{l}\text { Datang } \\
\text { Telecom } \\
\text { Technology } \\
\text { Co. Ldt } \\
\end{array}$ & $\begin{array}{l}\text { Panda } \\
\text { Electronics } \\
\text { Group Co. } \\
\text { Ldt } \\
\end{array}$ & $\begin{array}{l}\text { Putian } \\
\text { Communicatio } \\
\text { n Group Co. } \\
\text { Ldt } \\
\end{array}$ & $\begin{array}{l}\text { TCL } \\
\text { Communication } \\
\text { Equipment Co. } \\
\text { Ldt }\end{array}$ \\
\hline 1988- Foundation & $\begin{array}{l}1993 \\
\text { Foundation }\end{array}$ & $\begin{array}{l}1957 \\
\text { Foundation }\end{array}$ & $\begin{array}{l}1996 \\
\text { Foundation }\end{array}$ & $\begin{array}{l}1980 \\
\text { Foundation }\end{array}$ & $\begin{array}{l}1985 \\
\text { Foundation }\end{array}$ \\
\hline $\begin{array}{l}\text { 1990-1997 } \\
\text { Opens R\&D } \\
\text { Centres in China } \\
\text { Alliances with } \\
\text { foreign companies } \\
\text { in China }\end{array}$ & $\begin{array}{l}1993-2000 \\
\text { No investments in the } \\
\text { local market }\end{array}$ & $\begin{array}{l}\text { 1998-2004 R\&D } \\
\text { Opens China; } \\
\text { centres in Ch alliances } \\
\text { Realizes foreign } \\
\text { with China } \\
\text { companies in Che }\end{array}$ & $\begin{array}{lr}- & \\
\text { Opens } & \text { R\&D } \\
\text { centres in China; } & \\
\text { Realizes alliances } \\
\text { with foreign } \\
\text { companies } \\
\text { China }\end{array}$ & $\begin{array}{l}\text { - } \\
\text { Realizes about } 40 \\
\text { joint venture with } \\
\text { foreign companies } \\
\text { in China }\end{array}$ & $\begin{array}{l}\text { - } \\
\text { No investments in } \\
\text { the local market }\end{array}$ \\
\hline $\begin{array}{l}2000-2003 \\
\text { Starts } \\
\text { Internationalization: } \\
\text { opens R\&D centres } \\
\text { in India } \\
\text { (Bangalore), } \\
\text { Russia, Sweden } \\
\text { (Stockholm); } \\
\text { establishes a foreign } \\
\text { JV with Marconi in } \\
\text { GB. }\end{array}$ & $\begin{array}{l}2000-2004 \\
\text { Starts } \\
\text { Internationalization: } \\
\text { opens three R\&D } \\
\text { centres in Usa; one } \\
\text { centrs in Korea and one } \\
\text { in Sweden }\end{array}$ & $\begin{array}{l}2004 \\
\text { Starts } \\
\text { Internationalization } \\
: \text { realizes Fdi in } \\
\text { Iran and Latin } \\
\text { America }\end{array}$ & $\begin{array}{l}2001 \\
\text { Starts } \\
\text { Internationalizatio } \\
\mathrm{n} \text { Strategy : } \\
\text { realizes an R\&D } \\
\mathrm{JV} \text { in Usa and a } \\
\text { marketing centre } \\
\text { in Los Angeles }\end{array}$ & $\begin{array}{l}2002 \\
\text { Stars } \\
\text { Internationalization: } \\
\text { opens an R\&D } \\
\text { centre in the Silicon } \\
\text { Valley (USA) } \\
\text { Acquires a minority } \\
\text { stake in Interwave } \\
\text { Communication } \\
\text { International (US } \\
\text { wireless technology } \\
\text { equipment } \\
\text { manufacturer) }\end{array}$ & $\begin{array}{l}2005 \\
\text { Starts } \\
\text { Internationalization } \\
\text { : creates a JV in } \\
\text { France with } \\
\text { Alcatel. After nine } \\
\text { months acquires the } \\
\text { total ity of the } \\
\text { venture shares. }\end{array}$ \\
\hline $\begin{array}{l}2003 \\
\text { Reinforces the } \\
\text { competitive } \\
\text { position in the local } \\
\text { market and } \\
\text { becomes industry } \\
\text { leader }\end{array}$ & $\begin{array}{l}2000 \\
\text { Becomes leader in the } \\
\text { local market launching } \\
\text { the first mobile phone } \\
\text { with SIM card in China }\end{array}$ & & & & \\
\hline $\begin{array}{l}2004 \\
\text { Starts the second } \\
\text { phase } \\
\text { internationalization: } \\
\text { signs agreements } \\
\text { with the most } \\
\text { important TLC } \\
\text { companies in } \\
\text { Kenya, Nigeria, } \\
\text { Zimbawe }\end{array}$ & $\begin{array}{l}2004-2006 \\
\text { Starts the second phase } \\
\text { of internationalization: } \\
\text { opens productive } \\
\text { centres in } \\
\text { Russia, Brasile, Etiopia }\end{array}$ & & & & \\
\hline $\begin{array}{l}2006 \\
\text { Realizes Fdi in } \\
\text { Morocco, Egypt } \\
\text { and Ivory Cost } \\
\text { Acquires a minority } \\
\text { stake in } \\
\text { Intercellu lar Nigeria } \\
\text { Ltd (mobile TLC } \\
\text { operator) }\end{array}$ & 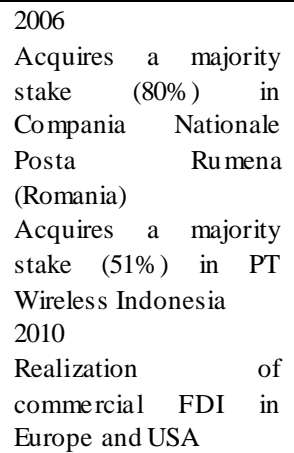 & & & & \\
\hline
\end{tabular}

The analysis of companies' internationalization reveals that these firms often realize FDIs, through the acquisition of the existing firms or the realization of joint ventures with foreign multinationals, into countries characterized by a high socio-economic development level as these countries have an industrial tradition in the communications equipment industry.

Adopting the proposed theoretical model it is evident that the majority of the firms are localized in the knowledge seeking quadrant. In fact, starting from a low level of competitiveness in the Chinese Telecommunication Equipment market, these firms realize FDIs in countries characterized by a high socio-economic development level in order to acquire the strategic assets nece ssary to reinforce their competitive 
position in the home country.

Only Datang adopts a different strategy because it realizes FDIs in countries characterized by a low socio-economic development level in order to exploit its positive competence gap over local competitors.

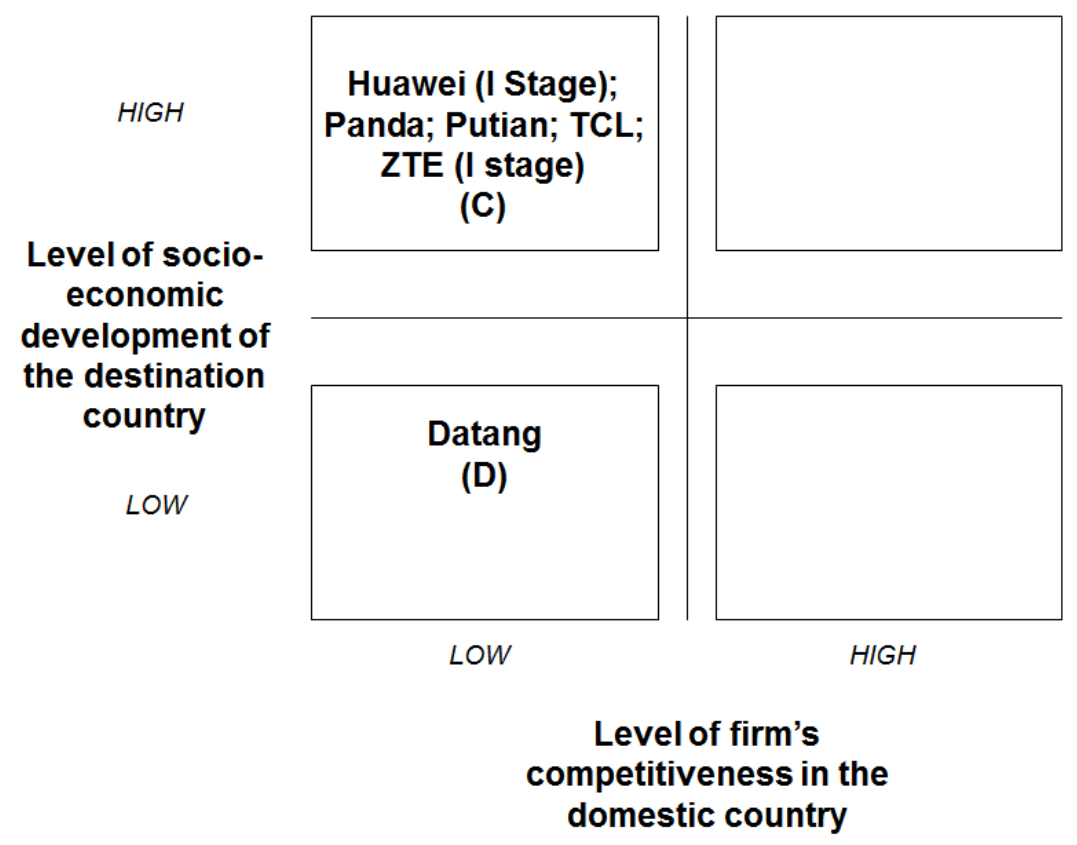

Figure 2. The determinants of international expansion of Chinese Telecommunication Equipment Manufactures

Examining the international expansion of the six multinationals in a dynamic way, two companies, Huawei and ZTE, appear to be implementing changes in their international strategy. In fact, having acquired the knowledge necessary to become leaders in the domestic market through the realization of FDIs in de veloped countries, they have invested in other emerging countries, where they have exploited the location specific advantages and increase their international market share. Huawei in more recent years has changed again its strategy investing in advanced countries to explore its competitive advantage in Western Countries and becomes global leader.

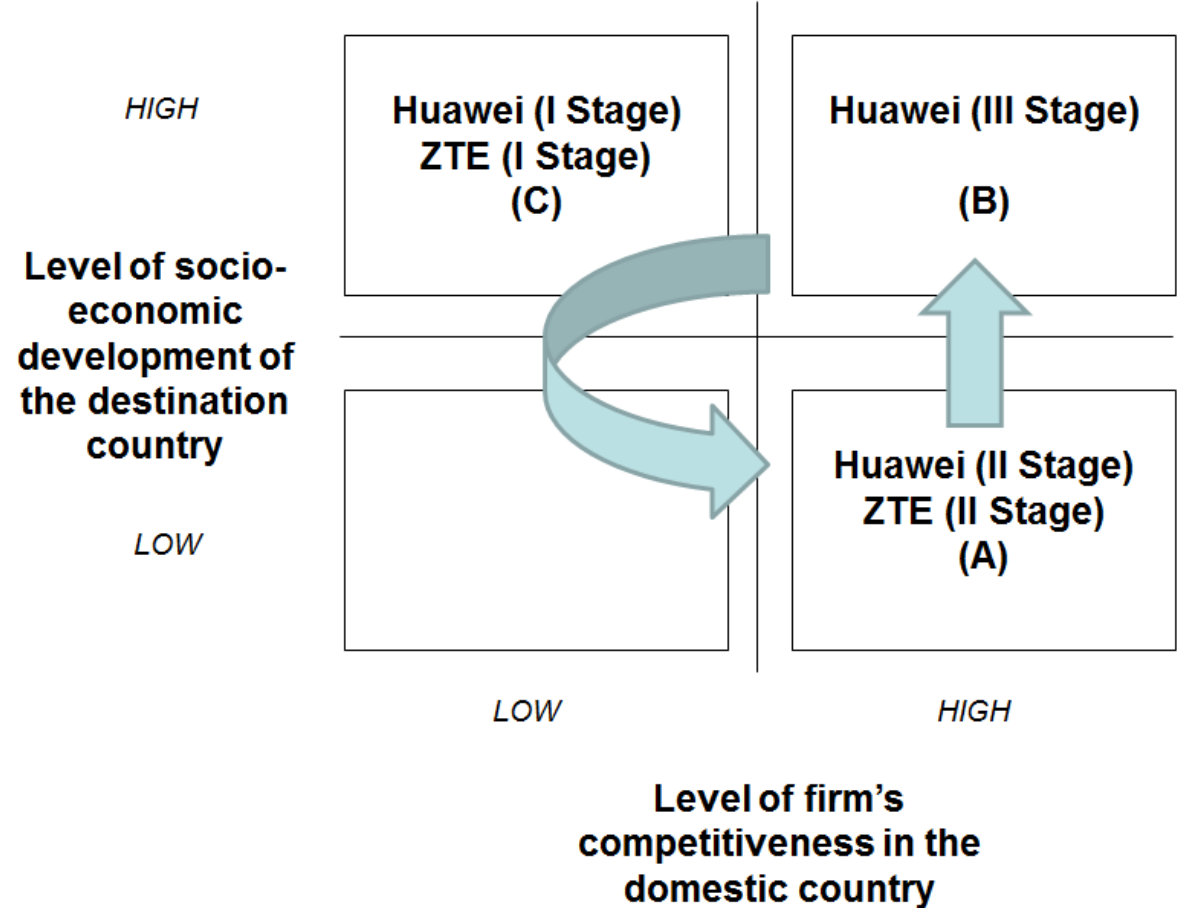

Figure 3. The determinants of international expansion of Chinese Telecommunication Equipment Manufactures in a dynamic perspective 


\section{Conclusions}

Over the past two decades, Chinese multinationals have made a huge amount of foreign direct investments abroad, making China the largest outward investor among the top ten emerging countries. Chinese multinationals are present also in the top 500 Fortune companies. The peculiarities of Chinese investments are that they are directed both towards other developing countries and towards advanced economies and that they regard both lower-end industries and higher-value adding activities.

Nevertheless, the remarkable expansion of Chinese companies cannot be explained by adopting the traditional internationalization theories based on the concept of ownership advantage. Accordingly, having shown that the existing literature is not equipped to explain the internationalization of Chinese companies, four different determinants that induce Chinese MNEs to make FDIs abroad are identified- knowledge seeking, competence gap exploitation, location specific advantage exploitation and global leadership acquisition. The application of this theoretical model for the analysis of the internationalization process of six Chinese Telecommunication Equipment Manufactures shows that, in the first stage of their internationalization process, many companies' primary aim is to survive. Consequently, they invest in specific countries where they can acquire the strategic assets necessary to win the competitive battle in the home market. Moreover, some of the analyzed companies, having acquired the knowledge necessary to become leaders in the domestic market through the realization of FDIs in developed countries, begin to internationalize in other emerging countries to increase their size and efficiency.

In conclusion, what seems to induce the Chinese MNEs to realize FDIs is the necessity to acquire the strategic assets useful to reinforce their competitive position in the domestic market. However, this motivation seems to be only a transition phase of their international development, because many companies that have started this strategy in the few years have reached a strong position of global leadership.

These conclusions should be considered as a starting point for future research aimed at providing a complete picture of all the factors that may influence the international strategy of Chinese multinationals.

\section{References}

Almeida, P. (1996). Knowledge sourcing by foreign multinationals: patent citation analysis in the U.S. semi-conductor industry. Strategic Management Journal, 17(Winter), 155-165. https://doi.org/10.1002/smj.4250171113

Andersen, O. (1993). On the internationalization process of firms: A critical analysis. Journal of International Business Studies, 24(2), 209-232. https://doi.org/10.1057/palgrave.jibs.8490230

Buckley, P. J., \& Casson, M. (1976). The Future of the Multinational Enterprise. London: Macmillan. https://doi.org/10.1007/978-1-349-02899-3

Caves, R. E. (1971). International Corporations: The Industrial Economics of Foreign Investment. Economica (New series), 38, 1-27.https://doi.org/10.2307/2551748

Cavusgil, S. T. (1980). On the internationalization process of firms. European Research, 8(November), 273-281.

Chandler, A. D. (1977). The Visible Hand: The Managerial Revolution in American Business. Cambridge Mass: Belknap Press of Harvard University.

Chang, S. J. (1995). International Expansion Strategy of Japanese Firms: Capability Building through Sequential Entry. Academy of Management Journal, 38, 383-407. https://doi.org/10.2307/256685

Child, J., \& Rodrigues, S. B. (2005). The internationalisation of Chinese firms: a case for theoretical extensions? Management and Organization Review, 1(3), 381-410. https://doi.org/10.1111/j.1740-8784.2005.0020a.x

Coase, R. H. (1937). The nature of the Firm. Economica, 4, 386-405. https://doi.org/10.1111/j.1468-0335.1937.tb00002.x

Dawar, N., \& Frost, T. (1999), Competing with Giants. Survival strategies for local companies in emerging markets, Harvard Business Review, March-April 1999, 119-129.

Deng P. (2004). Outward investment by Chinese MNCs: Motivations and implications. Business Horizons, 47, 8-16. https://doi.org/10.1016/S0007-6813(04)00023-0

$\mathrm{Du}$ Y. (2003). A challenge to traditional stages models of internationalisation. An empirical research on a Chinese company's successful internationalizing processes, paper presented at EAMSA 20th Annual Conference, 2003, Stockholm University School of Business. 
Dunning, J. H. (1988). Multinationals, Technologyand Competitiveness. London: Allen and Unwin.

Dunning, J. H. (1993). Multinational enterprises and globaleconomy, Wokingham, UK: Addison-Wesley.

Dunning, J. H. (1998). Location and the Multinational Enterprise: A Neglected Factor?, Journal of International Business, 29(1), 45-66. https://doi.org/10.1057/palgrave.jibs.8490024

Eisenhardt, K. M. (1989). Building Theories from Case Study Research. Academy of Management Review, 14(4), 532-550.

Erramilli, M. K., Agarwal, S., \& Seong-Soo, K. (1997). Are Firm-Specific Advantage Location Specific Too? Journal of International Business Studies, 28(4), 735-757. https://doi.org/10.1057/palgrave.jibs.8490117

Ferrantino, M. J. (1992). Transaction costs and the expansion of Third-World Multinationals. Economics Letters, 38(4). https://doi.org/10.1016/0165-1765(92)90033-U

Ghymn, K. I. (1980). Multinationals enterprises from the Third World. Journal of International Business Studies, 11(2), 118-122. https://doi.org/10.1057/palgrave.jibs.8490870

Gillham, B. (2000). Case Study Research Methods, New York: Continuum.

Hennart, J. E. (1982). A theory of multinational enterprise, Ann Arbor: Michigan University Press.

Hong, E., \& Sun, L. (2004). Go Overseas via Direct Investment: Internationalisation Strategy of Chinese Corporations in a Comparative Prism, from www.cefims.ac.uk/cgi-bin/research.cgi ?id=28 - 15k

Hymer, S. H. (1976). The International Operations of National Firms: A Study of Direct Foreign Investments. Cambridge, Mass: MIT Press (Ph.D thesis 1960).

Johanson, J., \& Vahlne, J. E. (1977). The internationalization process of the firm-a model of knowledge development and increasing market commitments, Journal of International Business Studies, 8 (Spring/Summer), 23-32. https://doi.org/10.1057/palgrave.jibs.8490676

Khan, K. M. (1986), Multinationals from the South: emergence, patterns and issues, in Khan K.M. (1986), Multinationals of the South. New York, St Martin's Press.

Knickerbocker, F. T. (1973). Oligopolistic Reaction and Multinational Enterprises, Cambridge Mass:Harvard University Press.

Kogut, B., \& Chang, S. J. (1991), Technological capabilities and Japanese foreign investments in the United States. Review of Economics and Statistics, 73(3), 401-413. https://doi.org/10.2307/2109564

Kumar, K. (1982), Third World Multinationals: A Growing Force in International Relations. International Studies Quarterly, 26(3), 397-424. https://doi.org/10.2307/2600427

Lall, S. (1984). The New Multinationals: the Spread of Third World Enterprises, New York: Wiley.

Lecraw, D. J. (1977), Direct Investment by Firms from Less Developed Countries. Oxford Economic Papers, 29, 442-457. https://doi.org/10.1093/oxfordjournals.oep.a041380

Lecraw, D. J. (1993). Outward Direct Investment by Indonesian Firms: Motivation and Effects. Journal of International Business Studies, 24(3), 589-600. https://doi.org/10.1057/palgrave.jibs.8490247

Liu, H., \& Li, K. (2002). Strategic implications of emerging Chinese multinationals: the Haier case study. European Management Journal, 20(6), 699-706. https://doi.org/10.1016/S0263-2373(02)00119-6

McManus, J. C. (1972). The Theory of the International Firm In G. Paquet (ed) The Multinational Firm and the Nation State. Toronto: Collier-Macmillan.

Moon, H. C., \& Roehl, T. W. (2001). Unconventional foreign direct investment and the imbalance theory, International Business Review, 10. https://doi.org/10.1016/S0969-5931(00)00046-9

Penrose, E. T. (1959). The theory of the growth of the firm, New York: Wiley.

Redding S. G. (1995). Overseas Chinese networks: understanding the enigma. Long Range Planning, 28(1), 61-69. https://doi.org/10.1016/0024-6301(94)00071-C

Reid, S. D. (1981). The decision-maker and export entry and expansion. Journal of International Business Studies, 12Fall, 101-112. https://doi.org/10.1057/palgrave.jibs.8490581

Rugman, A. M. (1981). Inside the Multinationals: The Economics of Internal Markets, New York: Columbia University Press.

Rugman, A. M. (1982). New theories of the multinational enterprise. New York: St. Martin's Press. 
Schroath, F. W., Hu, M. Y., \& Chen, H. (1993). Country-of-Origin Effects of Foreign Direct Investment in the People's Republic of China. Journal of International Business Studies, Second Quarter, 277-290. https://doi.org/10.1057/palgrave.jibs.8490233

Tolentino, P. E. (1993). Technological Innovation and Third World Multinationals, London: Routledge.

Vernon, R. (1966). International Investment and International Trade in the Product Cycle. Quarterly Journal of Economics, 80, 190-207. https://doi.org/10.2307/1880689

Wells, L. T. Jr. (1981). Foreign Investors from the Third World, in Kumar K. and McLeod M.G. (1981), Multinationals from Developing Countries, Lexington Books, New York.

Wells, L. T. Jr. (1981), Foreign Investors from the Third World: The experience of Chinese firms from Hong Kong. Columbia Journal of World Business, Spring 1978, 39-49.

Williamson, O. E. (1975) Markets and Hierarchies: Analysis and Anti-Trust Implications. New York: Free Press.

Wu, F. (2005). Corporate China goes global, from www.cctr.ust.hk/articles/200509 _corporate .pdf

Yeung, H. W. (1999). The internationalization of ethnic Chinese business firms from Southeast Asia: strategies, processes and competitive advantage. International Journal of Urban and Regional Research, 23. https://doi.org/10.1111/1468-2427.00181

Yin, R. K. (1994). Case Study Research: Design and Methods (2nd ed.), Sage Publications, Thousand Oaks, CA.

\section{Copyrights}

Copyright for this article is retained by the author(s), with first publication rights granted to the journal.

This is an open-access article distributed under the terms and conditions of the Creative Commons Attribution license (http://creativecommons.org/licenses/by/4.0/). 